\title{
OCCURRENCE OF CAMPYLOBACTER JEJUNI IN DOG FAECES FROM THE STREETS OF A SOUTHERN CHILEAN CITY (1)
}

\author{
H. FERNANDEZ (2) \& V. ARNES (2)
}

\section{$\mathbf{S} \mathbf{U} \mathbf{M} \mathbf{M} \mathbf{A} \mathbf{Y}$}

Dog faeces collected from the streets of a southern chilean city were cultured on selective media for thermophilic campylobacters. Campylobacter jejuni (bio. type 1) was isolated from $53(35.3 \%)$ of 150 samples. The use of an enrichment medium enhanced in $20.8 \%$ the isolation rate of this bacteria.

KEY WORDS: Campylobacter jejuni; Occurrence in dog faeces - Chile.

\section{N T R O D U G T I O N}

Campylobacter jejuni is now world-wide recognized as a zoonotic agent of bacterial diarrhoea in human beings 2,12 . Many domestic animals are intestinal carriers of these bacteria and could be a probable source of human infection 7,12. Dogs, particulary puppies, may be responsible for the transmission of Campylobacter to human contacts. Campylobacter isolation rates varies between $6-52.2 \%$ depending on the group of dogs studied. Stray and kenneled dogs show the highest frequencies of these bacteria in their faeces 10,12 . In southern Chile, the isolation rate of Campylobacter was $51 \%$ in the first semester 19844.

The aim of this study was to determine the incidence of $\mathbf{C}$. jejuni in dog faeces collected from the streets of a southern chilean city and the role that this biological material plays as a possible source of Campylobacter infection.

\section{MATERIAL AND METHODS}

During a four month period from April to July 1985, 150 samples of dog faeces were collected from the streets of Valdivia, a southern chilean city (southern latitude 39'48'; 140,000 habitants). All the samples examined were freshlooking faeces and each specimen was inoculated directly onto Skirrow's compylo. bacter selective medium ${ }^{12}$ and into a semi-solid enrichment medium containing per liter: brucella broth $28 \mathrm{~g}$, agar $1.6 \mathrm{~g}$, distilled water $950 \mathrm{ml}$, horse blood $50 \mathrm{ml}$, polymixin B sul. phate $2,500 \mathrm{i} . \mathrm{u}_{\text {., }}$ rifampicin $10 \mathrm{mg}$ and trimethoprim lactate $5 \mathrm{mg}$. After overnight incubation the enrichment medium was subcultured onto Skirrow's medium. All cultures were incu. bated at $43^{\circ} \mathrm{C}$ in a microaerobic atmosphere using the GasPak system w/o catalizator. Plates were examined after $48 \mathrm{~h}$ and Gram stain oxidase and catalase reactions were done from the suspected colonies. All Campylobacter isolates were biotyped using the scheme proposed by SKIRROW \& BENJAMIN ${ }^{13}$.

\section{RESULTS}

The results obtained show that $53(35.3 \%)$ out 150 dog faeces examined yielded $C$. jejuni. The enrichment procedure enhaced the isolation rate in $20.8 \%$. From the $\mathbf{5 3}$ isolates, 42 were direct plate positive/enrichment positive and 11 were made with the help of the enrichment procedure.

C. jejuni biotype 1 was the only one isolated. We did not found the other termophilic campylobacter blotypes.

(1) Financial support: Grant 5-84-1, Research \& Development Bureau, Universidad Austral de Chile

(2) Institute of Clinical Microbiology, Universidad Austral de Chile, Valdivia - Chile 
FERNANDEZ, H. \& ARNES, V. - Occurrence of Campylobacter jejuni in dog faeces from the streets of a Southern Chilean city. Rev. Inst. Med. trop. São Paulo, 28:410-412, 1986.

\section{DISCUSSION}

Our results show that the incidence of $\mathbf{C}$. jejuni in dog faeces collected in the streets of our city was relatively high $(35.3 \%)$. They agree 'with the studies of RICHARDSON \& $\mathrm{KO}$. ORNHOF 9 who reported that $36 \%$ of freshly voided dog faeces collected from pavements yielded Compylobacter. However, the frequency of contamined faeces is lower than the one observed when dogs are directly samplied? $(50 \%)^{4}$. WRIGHT ${ }^{15}$ reported that $4.6 \%$ of the dog faeces collected in a public park were contamined with Compylobacter. The difference could be explained if we take into consideration that most of the samples studied by WRIGHT 15 were obtained from animals belonging to knew owners which may indicate a good standard of care. Althoungh most of the dogs seen in the streets of our city could have an owner, they can not be differentiated from true stray dogs because they loiterer habits are reflecting a bad standard of care. Remarkable differences exist in the inccidence of intestinal carriage of Com. pylobacter among stray dogs and pet dogs 3,10 .

The use of an enrichment medium enhanced the isolation rate in $20.8 \%$. Using enrichment procedures in human faecal samples, SKIRROW \& BENJAMIN 14 and RIBEIRO, GRAY \& PRICE ${ }^{8}$ obtained an increase of positive cases of 5.6 and $29.3 \%$ respectively. The use of enrichment culture seems to be necessa. ry in samples in which the anticipated number of campylobacter organisms is $10 \mathrm{w}^{6}$. This statement and the results obtained in our work make the use of enrichment procedures desirable for the isolation of Campylobacter in epidemiological studies.

C. jejuni in náturally infected human faeces held at $25^{\circ} \mathrm{C}$ did not survive for more than 7 days '. Under experimental conditions C. jejuni resists dessication for periods that varies between 2 and $10 h^{5}$. The survival of C. jejuni in faeces naturally exposed to environmental conditions is an epidemiological factor that needs further clarification.

Since direct contact of humans with dog faeces deposited in streets and other public places is remote, they may constitute a most important suorce for the transfer of these organisms to sparrows $-40 \%$ of them are intestinal carriers of Campylobacter (4) -and other birds, increasing the dissemination possibilities of zoonotic thermophilic campylobacters.

\section{RESUMO}

Ocorrência de Campylobacter jejuni em fezes caninas recolhidas das ruas de uma cidade do sul do Chile.

Amostras de fezes caninas recolhidas das ruas de uma cidade do sul do Chile foram semeadas em meios seletivos para as espécies termófilas de Campylobacter.

Campylobacter jejuni (biotipo 1) foi isolado de $53(35.3 \%)$ das 150 amostras estudadas. O emprego de um meio de enriquecimento aumentou em $20,8 \%$ a frequiência de isolamento desta bactéria.

\section{REFERENCES}

1. BLASER, M. J.; HARDESTY, H. L.; POWERS, B. \& WANG, W. L. L. - Survival of Campylobacter fetus subsp. jejuni in biological milieus. J. clin. Microbiol., 11: $309-313,1980$.

2. BLASER, M. J. \& RELLER, L. B. - Campylobacter interitis. New Engi. J. Med., äus: 1444.1452, 1981.

3. BRUCE, D.; ZOCHOWSKI, W. \& FLEMING, G. A. Campylobacter infections in cats and dogs. Vet. Rec., 107: 200-201, 1980.

4. FERNANDEZ, H. - Species and biotype distribution of thermophilic campylobacters in animal reservoirs in Southern Chile. Third International Workshop on Campylobacter infections. Ottawa. Canada, 1985. Code n. 115.

5. FERNANDEZ, H. - Dessication resistence in thermotolerant Campylobacter species. Infection, 13: 197, 1985.

6. HUNTCHINSON, D. N. \& BOLTON, F. J. - Is enrichment culture necessary for the isolation of Cam. pylobacter jejuni from faeces? J. clin. Path., 35: 1350-1352, 1983.

7. PRESCOTT, J. F. \& MUNROE, D. L. - Campylobacter jejuni enteritis in man and domestic animals. J. Amer. vet. med. Ass., 181: 1524-1530, 1982.

8. RIBEIRO, C. D.; GRAY, S. J. \& PRICE, T. H. - Is enrichment culture necessary for the isolation of Campylobacter jejuni from faeces? J. clin. Path., 37: 479, 1984.

9. RICHARDSON, N. J. \& KOORNHOF, H. J. - Cam. pylobacter infections in Soweto. S. Afr. med. J., 55: 73-74, 1979.

10. SIMPSON, J. W.; BURNIE, A. G.; FERGUSON, S. \& TEHFER BRUNTON, W. A. - Isolation of thermophilic 
FERNANDEZ, H. \& ARNES, V. - Occurrence of Campylobacter jejnni in dog faeces from the streets of a Southern Chilean city. Rev. Inst. Met. trop. Sāo Paulo, 28:410-412, 1986.

campylobacters from two populations of dogs. Vet. Res. Commun., 5: 63-66, 1981.

11. SKIRROW, M. B. - Campylohacter enteritis: a "new" disease. Brit. med. J., 2: 9-11, 1977.

12. SKIRROW, M. B. - Campylobacter enteritis in dogs and cats: a "new" zoonosis. Vet. Res. Commun., 5: $13-19,1981$

13. SKIRROW, M. B. \& BENJAMIN, J. - Differentiation of enteropathogenic campylobacter. J. clin. Path., 33: $1122,1980$.
14. SKIRRWO, M. B. \& BENJAMIN, J. - Is enrichment culture necessary for the isolation of Campylobacter jejuni from faeces? J. clin. Path., 37: 478, 1984.

15. WRIGHT, E. P. - The occurrence of Campglobacter jejuni in dog faeces trom a public park. J. Hyg., 89: 191.194, 1982.

Recebido para publicação em 31/12/1985. 